\title{
Udder health in Canadian dairy heifers during early lactation
}

\author{
S. Ali Naqvi, ${ }^{*}$ Jeroen De Buck, ${ }^{*}$ Simon Dufour,t and Herman W. Barkema*1 \\ *Department of Production Animal Health, Faculty of Veterinary Medicine, University of Calgary, Calgary, AB, Canada, T2N 2T8 \\ †Department of Pathology and Microbiology, Faculty of Veterinary Medicine, University of Montreal, Saint-Hyacinthe, QC, Canada, J2S 2M2
}

\section{ABSTRACT}

Mastitis is the most prevalent and costly disease in dairy cattle worldwide, with implications for animal health and welfare as well as production and economics. Nonlactating heifers are an often-neglected group of animals concerning mastitis management, as they are assumed to be free of mastitis. An observational field study was conducted between 2007 and 2008 on 91 dairy herds across Canada, representative of provincial averages of bulk milk somatic cell count (BMSCC) and barn type. The aims of that study were to (1) estimate in early-lactating heifers overall and pathogen-specific incidence rate of clinical mastitis (IRCM), prevalence of intramammary infection (IMI), and prevalence of subclinical mastitis (SCM; defined as SCC $\geq 200,000$ cells/ $\mathrm{mL})$; (2) compare these udder health parameters between heifers and multiparous cows; and (3) determine regional patterns and variations in these udder health parameters across BMSCC categories. During the first day of lactation, IRCM was higher in heifers than in multiparous cows (99 vs. 48 cases per 10,000 quarterdays at risk, respectively). Clinical mastitis affected $4 \%$ of heifers (0.73 cases per 100 quarters) in the first 30 $\mathrm{d}$ after calving, with the most common pathogens isolated being Staphylococcus aureus and Escherichia coli, whereas $S$. aureus and non-aureus staphylococci were the most commonly isolated pathogens in multiparous cows. The IRCM in heifers was highest in Ontario heifers, but overall IRCM did not vary by BMSCC category and it was only higher in multiparous cows than heifers in high-BMSCC Ontario herds. Intramammary infections were present in $33 \%$ of heifer quarters, with non-aureus staphylococci the most commonly isolated group of bacteria in both heifers (26\% of quarters) and multiparous cows (18\% of quarters). Pathogen-specific prevalence of IMI did not differ between heifers and multiparous cows, but we noted regional differences and differences across BMSCC categories in pathogen-

Received July 26, 2017.

Accepted December 11, 2017.

${ }^{1}$ Corresponding author: barkema@ucalgary.ca specific prevalence of IMI. Prevalence of SCM in heifers was $13.6 \%$ and was lowest in Alberta herds. In all regions, SCM prevalence was higher in multiparous cows than in heifers. In conclusion, udder health of Canadian dairy heifers was similar to that of other countries, demonstrating the importance of the issue. Differences between heifers and multiparous cows early in lactation highlighted the need for management practices to target the precalving period in heifers, when exposure to risk factors differs from that in lactating cows.

Key words: heifer mastitis, epidemiology, CNS, environmental, infectious

\section{INTRODUCTION}

Dairy heifers are typically not a focus when it comes to mastitis prevention and detection on farms, as they are not lactating and free from the physical and physiological stresses associated with the milking process (De Vliegher et al., 2012). However, the incidence of clinical mastitis (CM) and prevalence of subclinical mastitis (SCM) is high in heifers around calving, and the effect of $\mathrm{CM}$ on heifers is more severe than that in older animals (Piepers et al., 2009). Heifers that calve with SCM or $\mathrm{CM}$ are more likely to be culled during their first lactation, and persistence of mastitis into lactation has a stronger effect on future udder health and milk production (Piepers et al., 2009). Raising an animal to first calving represents a considerable investment that may not be recuperated over the course of a single lactation, and, as such, there is a strong economic incentive for prevention and management of mastitis around calving in heifers (Rollin et al., 2015).

Mean incidence rate of CM (IRCM) on dairy farms ranges from 20 to $30 \mathrm{CM}$ cases/100 cow-years at risk (Olde Riekerink et al., 2008; Verbeke et al., 2014; Levison et al., 2016) in all lactating cows, but disease progression may be different in primiparous heifers. The incidence of both new IMI and CM in primiparous heifers are highest in the weeks before and immediately after calving, as rates are higher than in multiparous cows in early lactation (Barkema et al., 1998; De Vliegher et al., 2004; Moosavi et al., 2014). 
The distribution of bacterial species in milk samples from cows with $\mathrm{CM}$ varies with geographic region, bulk milk SCC (BMSCC), barn type, herd hygiene, and bedding type (Kalmus et al., 2006; Olde Riekerink et al., 2008; Verbeke et al., 2014; Rowbotham and Ruegg, 2016), whereas no study has quantified bacterial species distribution in CM cases from Canadian heifers. In lactating cows, Staphylococcus species often comprise a very large proportion of bacteria isolated from IMI and mastitis cases (Kalmus et al., 2006; Verbeke et al., 2014; Yang et al., 2015). In contrast, in heifers raised on pasture in New Zealand, Streptococcus uberis accounted for the majority of $\mathrm{CM}$ cases at calving (Pankey et al., 1991). In studies comparing bedding types in heifers housed indoors in the United States and China, CNS and Escherichia coli were the most prevalent CM pathogens (Yang et al., 2015; Rowbotham and Ruegg, 2016). The distribution of pathogens in CM cases differ in their long-term effect on udder health (Piepers et al., 2009; Supré et al., 2011), and affect primiparous cows differently than multiparous cows (Gröhn et al., 2004).

No study has been conducted in Canada to determine species-specific IRCM in heifers. Climate and management practices, including housing, vary considerably across Canada, the second largest country in the world. By determining risks and pathogens to which heifers are exposed, producers will be able to create better targeted and more effective management and treatment practices for mastitis. Establishing benchmarks for disease burden will also allow regional dairy marketing boards to better understand the scale of the problem, highlight gaps in knowledge and inform provincial decisions regarding research priorities. The objectives of our study were, therefore, to (1) determine the speciesspecific IRCM and prevalence of SCM (defined as SCC $\geq 200,000$ cells $/ \mathrm{mL}$ ) and IMI in Canadian dairy heifers in the first month of lactation; (2) compare these udder health parameters between primiparous heifers and multiparous cows; and (3) determine regional patterns and variation in these udder health parameters across BMSCC categories.

\section{MATERIALS AND METHODS}

\section{Herds and Samples}

Details and rationale of the selection of farms, as well as details regarding sampling, were described by Reyher et al. (2011). In short, data were collected from 91 farms in 6 Canadian provinces (17 in Alberta; 27 in Ontario; 29 in Quebec; and 8 in Prince Edward Island, 5 in Nova Scotia and 5 in New Brunswick, grouped together as Atlantic Canada) during 2007 and 2008.
Farms were selected to represent farms across Canada in 2006 based on lactating herd housing type $(81,9,28$, and $48 \%$ freestall barns in Alberta, Ontario, Quebec, and Atlantic provinces, respectively) and uniformly encompassing 3 strata of 12-mo geometric mean average BMSCC, classified as low, intermediate, and high $(<150,000,150,000$ to 300,000 , and $>300,000$ cells $/ \mathrm{mL}$, respectively). In the present study, BMSCC herds were classified as low, intermediate, and high with cut-offs of $<150,000,150,000$ to 250,000 , and $>250,000$ cells $/ \mathrm{mL}$, respectively, to account for decreased herd BMSCC in the years following data collection. All farms enrolled in the study had at least $80 \%$ Holstein-Friesian cows in their herds, milked twice a day, and were enrolled in their regional DHI recording system.

From February 2007 to December 2008, participating farmers were asked to identify cows with CM, based on abnormal milk or more severe signs of mastitis, and submit a quarter-milk sample on the day of $\mathrm{CM}$ diagnosis (Reyher et al., 2011). A total of 16 of the 91 herds were excluded from the current study because, when audited, they recorded $<80 \%$ of $\mathrm{CM}$ cases (Dufour et al., 2011). A nonclinical lactating longitudinal milk sampling series was also conducted to determine the prevalence of IMI in cows considered clinically normal. Ten lactating cows were selected randomly along with the 5 most recently calved cows for sampling. All quarter milk samples were collected from these 15 cows by Canadian Bovine Mastitis Research Network (CBMRN, Saint-Hyacinthe, QC, Canada) technicians 3 times every 3 wk during the spring of 2007 and during 2008. During the summer of 2007, an intensive sampling period consisted of 7 samples collected daily for $1 \mathrm{wk}$. Each animal in the nonclinical longitudinal study had either 3 or 7 samples taken, depending on the sampling period, whereas no samples were taken before March 2007, between September and December 2007, or after August 2008. In this study, only samples collected during the first 30 DIM were considered. Furthermore, although bacteriological findings were reported from all samples collected during the 30 DIM period, prevalence estimates were based on only the earliest sample from each animal during that period (to ensure consistency of IMI definition). Of the included records, 1,267 cows were sampled once, 1,730 were sampled twice, 262 were sampled 3 times, 126 were sampled 4 times, 50 were sampled 5 times, 22 were sampled 6 times, and 8 were sampled 7 times. Prevalence of SCM during the first 30 DIM were estimated from DHI milk records. Subclinical mastitis was defined as a composite milk SCC $\geq 200,000$ cells/mL in DHI composite milk samples. Although primiparous heifers differ from multiparous cows in their SCC patterns through lactation (de Haas et al., 2002, 
2004), a common threshold of 200,000 cells $/ \mathrm{mL}$ was used for both groups of animals in this study, as this is a practical threshold that minimizes diagnostic errors (Schukken et al., 2003).

\section{Laboratory Analyses}

Details of sample processing protocol were described by Reyher et al. (2011). Briefly, milk samples collected by farm personnel (CM series) were stored on farm until monthly pickup by technicians, whereas samples collected by CBMRN technicians were immediately sent to 1 of 4 CBMRN laboratories for bacteriological culture and analysis. Before culture, non-CM samples were split and SCC was determined using a Fossomatic cell counter (Foss Electric, Hillerød, Denmark). Bacteriological culturing and identification were conducted following a standardized protocol outlined in the National Mastitis Council guidelines (Hogan et al., 1999). If $>2$ species were isolated, the sample was considered contaminated, with the exception of Staph. aureus and Staph. agalactiae, in which case the species was still identified and quantified. For the purposes of defining IMI in the present study, an IMI by a particular species was defined as having $\geq 1$ colonies formed from $10 \mu \mathrm{L}$ of inoculum in mixed or pure culture, with no minimum SCC requirement (Dohoo et al., 2011b). Pathogens were grouped into 4 categories: contagious pathogens (Staph. aureus, Streptococcus dysgalactiae, Streptococcus agalactiae), environmental pathogens (Escherichia coli, Klebsiella spp., Enterobacter spp., Nocardia spp., Prototheca spp., Trueperella pyogenes), non-aureus staphylococci (NAS), and other pathogens (other bacteria, yeasts, and fungi). As IMI by up to 2 pathogens was possible, a single quarter could be included in multiple pathogen groups.

\section{Statistical Analyses}

Data organization and reshaping were done with $\mathrm{R}$ version 3.4.2 (R Core Team, 2017), whereas statistical analyses of disease and species distribution used the "geepack" (Halekoh et al., 2006) and the "Ime4" (Bates et al., 2015) packages. A $P$-value $<0.05$ was considered significant. Statistical analyses were conducted for 3 outcomes: CM, IMI, and SCM.

$\boldsymbol{C M}$. The 30-DIM IRCM was calculated at the quarter level, with the population at risk determined from DHI records. Marginal models using generalized estimating equations were used to estimate parameters. Preliminary unconditional analyses detected no evidence of overdisperion; therefore, a Poisson distribution was selected for all analyses. Only the herd-level correlation structure was included, as using the sandwich estimator for variance accounts for any nested clustering effects within the highest cluster (Betensky et al., 2000). Parity (dichotomized between heifers and multiparous cows) and either region (Alberta, Ontario, Quebec, and Atlantic Canada) or BMSCC $(<150,000$; 150,000-250,000; or $>250,000$ cells $/ \mathrm{mL}$ ) were included as predictors, as well as interaction terms between parity and the other predictor to allow stratum-specific estimates. For within-BMSCC comparisons, a subgroup analysis stratified by region was conducted. One model compared overall IRCM between heifers and multiparous cows, whereas the other 4 compared pathogenspecific IRCM between heifers and multiparous cows. The model used for estimates of CM was

$$
\begin{gathered}
\ln \left(\mathrm{n} \mid \mathrm{Y}_{\mathrm{i}}\right)=\beta_{0}+\beta_{1} \text { Parity }+\beta_{2} \text { Region }+\beta_{3} \text { BMSCC } \\
+\beta_{4} \text { Parity } \times \text { Region }+\beta_{5} \text { Parity } \times \text { BMSCCi } \\
+\beta_{6} \text { Region } \times \text { BMSCC }+\beta_{7} \text { Region } \times \text { BMSCC } \\
\times \text { Parity }+\operatorname{Corr}\left(\mathrm{Y}_{\mathrm{i}}\right)+\ln (\mathrm{p})
\end{gathered}
$$

where $\left(n \mid Y_{i}\right)$ is the predicted number of overall or pathogen-specific clinical mastitis cases in herd i assumed to follow a Poisson distribution; $\beta_{1}$ to $\beta_{7}$ are regression coefficients for the predictors and their interactions; $\operatorname{Corr}\left(\mathrm{Y}_{\mathrm{i}}\right)$ is a correction based on the exchangeable correlation structure of observations within the same herd; $\ln (\mathrm{p})$ is the offset of the equation, and the natural logarithm of the population at risk. Marginal parameter estimates and predictions from generalized estimating equations represent population averaged estimates (average of all herds in Canada), in contrast to subject-specific estimates (for herds included in the study) provided by mixed effects models.

After approximately 15 DIM, daily IRCM in both heifers and multiparous cows remain fairly constant (Barkema et al., 1998). Therefore, the following model, including only parity, was used to compare differences in mean daily IRCM between heifers and multiparous cows for the first 15 DIM:

$$
\begin{aligned}
\ln \left(\mathrm{n} \mid \mathrm{Y}_{\mathrm{i}}, \mathrm{DIM}\right)= & \beta_{0}+\beta_{1} \text { Parity }+\operatorname{Corr}\left(\mathrm{Y}_{\mathrm{i}}\right)_{\mathrm{DIM}} \\
& +\ln \left(\mathrm{p}_{\text {DIM }}\right),
\end{aligned}
$$

where $\left(n \mid Y_{i}, D I M\right)$ is the predicted number of $C M$ cases that follow a Poisson distribution in herd $\mathrm{i}$ on a given DIM which ranged from 0 to $14 ; \beta_{1}$ is the $\log$ incidence rate ratio between heifers and multiparous cows; $\operatorname{Corr}\left(\mathrm{Y}_{\mathrm{i}}\right)$ is correction based on the exchangeable correlation structure of observations within the same herd on the given DIM; and $\ln \left(\mathrm{p}_{\mathrm{DIM}}\right)$ is the offset of the 
equation and the natural logarithm of the population at risk on the given DIM.

IMI. Prevalence of IMI in the first 30 DIM was calculated at the quarter level using the first sample taken per animal and lactation as part of the nonclinical longitudinal series during that interval, with population at risk determined from the total number of quarters sampled during the first 30 DIM. Mixed effects logistic regression models were fitted to determine differences in prevalence between groups, with random effects at the herd and animal levels. Estimation of model parameters was conducted via REML with Laplace approximation. Results were reported as odds, but the inverse logit function was used to present prevalence (for ease of interpretation) and differences were assessed by comparing odds ratios. The latter were not converted to risk ratios, as when dealing with common diseases (prevalence $>10 \%$ ), converted odds ratio overestimate the strength of the association (McNutt et al., 2003). The logit link was used instead of the log link, due to higher model convergence rates with the included random effects. Region, BMSCC, and parity were included as predictors, as they were for the CM models. Significance of differences across predictors, and their interactions with parity, were forced into the model for overall IMI prevalence and pathogen-specific prevalences to enable reporting of stratum specific estimates. The model used for IMI prevalence estimate was

$$
\begin{aligned}
\ln \left(\frac{\mathrm{p}}{1-\mathrm{p}}\right)_{\mathrm{jk}}= & \beta_{0}+\beta_{1} \text { Parity }+\beta_{2} \text { Region }+\beta_{3} \mathrm{BMSCC}_{\mathrm{k}}+ \\
& \beta_{4} \text { Parity } \times \text { Region }+\beta_{5} \text { Parity } \times \mathrm{BMSCC}_{\mathrm{k}}+ \\
& \beta_{6} \text { Region } \times \text { BMSCC }_{\mathrm{k}}+\beta_{7} \text { Region } \times \mathrm{BMSCC}_{\mathrm{k}} \times \\
& \text { Parity }+\mathrm{u}_{\mathrm{k}}+\mathrm{v}_{\mathrm{j}},
\end{aligned}
$$

where $\left(\frac{\mathrm{p}}{1-\mathrm{p}}\right)_{\mathrm{jk}}$ is the predicted quarter-level odds of having any or pathogen-specific IMI for animal $\mathrm{j}$ in herd $\mathrm{k}$, where $\mathrm{p}$ is assumed to follow a binomial distribution; $\beta_{1}$ to $\beta_{7}$ are regression coefficients for the predictors and their; $u_{k}$ is the random intercept term for herd, assumed to be normally distributed with a mean of 0 and a constant variance; and $\mathrm{v}_{\mathrm{j}}$ is the random intercept term for animal, assumed to be normally distributed with a mean of 0 and a constant variance and accounted for correlation between multiple quarters sampled within each animal. Parameter estimates from mixed effect generalized linear models represent the average of all the subject-specific estimates from model (average of all the herds and animals included in the study).
$\boldsymbol{S C M}$. Prevalence of SCM was calculated at the cow level using all DHI records available in the first 30 DIM. A mixed effects logistic regression model was used, with random effects at herd and animal levels. Estimation of model parameters was conducted via REML with Laplace approximation. The logit link was used again instead of the log link so that between-group comparisons were done using odds ratios. Region and parity were included as predictors, as they were for $\mathrm{CM}$ and IMI, and the significance of differences across predictors and interactions with parity were included to determine stratum-specific estimates of SCM prevalence. The model used for SCM prevalence prediction with stratification by region was

$$
\begin{aligned}
\ln \left(\frac{\mathrm{p}}{1-\mathrm{p}}\right)_{\mathrm{jk}} & =\beta_{0}+\beta_{1} \text { Parity }+\beta_{2} \text { Region }+\beta_{3} \text { Parity }_{\mathrm{j}} \times \text { Region } \\
& +\mathrm{u}_{\mathrm{k}}+\mathrm{v}_{\mathrm{j}},
\end{aligned}
$$

where $\ln \left(\frac{p}{1-p}\right)_{j k}$ is the predicted animal-level odds of having SCM for animal $\mathrm{j}$ in herd $\mathrm{k}$, where $\mathrm{p}$ is assumed to follow a binomial distribution; $\beta_{1}$ to $\beta_{3}$ are regression coefficients for the predictors and their interactions; $u_{k}$ is the random intercept term for herd and was assumed to be normally distributed with a mean of 0 and a constant variance; and $\mathrm{v}_{\mathrm{j}}$ is the random intercept term for animal and was assumed to be normally distributed with a mean of 0 and a constant variance.

All results presented are least squares means predictions from models with Wald confidence intervals; therefore, they are adjusted for clustering. In the case of IMI results, they were also adjusted for imperfect sensitivity and specificity using the following formula presented in Dohoo et al. (2014):

$$
\begin{gathered}
\text { True prevalence }=(\text { apparent prevalence } \\
+ \text { specificity }-1) /(\text { sensitivity }+ \text { specificity }-1) .
\end{gathered}
$$

Values for sensitivity and specificity were derived from Dohoo et al. (2011b), where values for Staph. aureus were used for contagious pathogens; E. coli values were used for environmental pathogens (more conservative than the Streptococcus values); CNS values were used for NAS; and values for "any pathogen" were used for the other pathogen category. Within-herd pairwise associations between rates of disease in heifers and multiparous cows and between different measures of disease in heifers (IRCM, IMI, and SCM) were assessed by computing the Pearson correlation coefficient between herd-specific estimates of incidence and prevalence. 


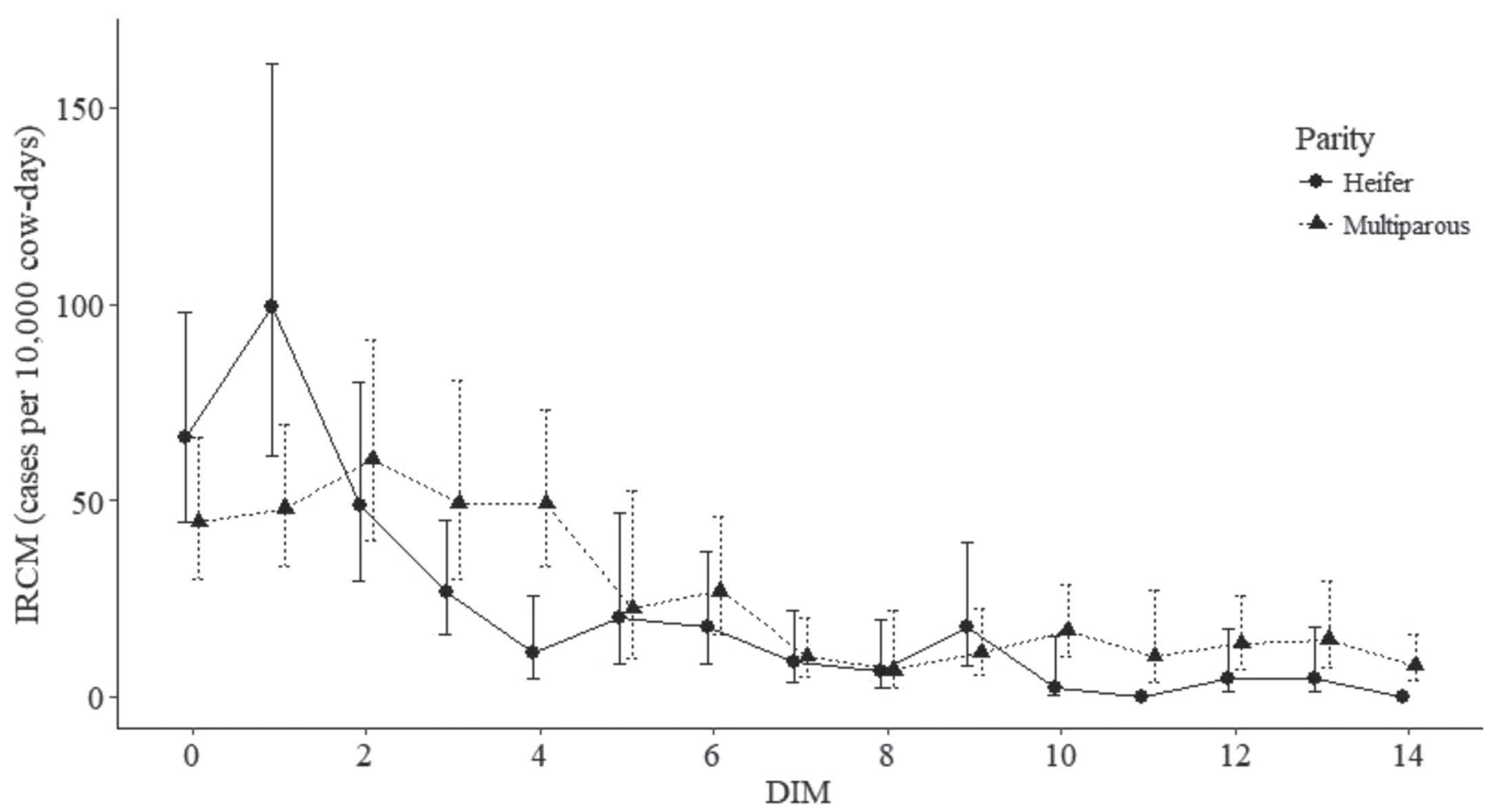

Figure 1. Incidence rate of clinical mastitis (IRCM) in the first $14 \mathrm{~d}$ of lactation in primiparous $(18,157$ quarter-months) and multiparous (35,936 quarter-months) dairy cows in Canada. Confidence intervals based on marginal models using generalized estimating equations.

\section{RESULTS}

\section{CM}

At the first DIM, IRCM in heifers (99 per 10,000 cow-days) was higher than in multiparous cows (incidence rate ratio $=0.67: P=0.01 ;$ Figure 1$)$. At 4 DIM, multiparous IRCM (49 per 10,000 cow-days) was higher than that in heifers (11 per 10,000 cow-days). After 4 DIM, the incidence curves for the 2 groups converged and were not different for the next 10 DIM. In heifer CM samples, NAS were the most commonly isolated pathogen, whereas in multiparous cow CM samples, Staph. aureus was the most commonly isolated pathogen (21 and 18\%, respectively; Table 1). Streptococcus agalactiae was not isolated from any heifer or multiparous cow with CM during the first 30 DIM.

Across Canada, IRCM in the first 30 DIM did not differ between BMSCC categories, with a combined IRCM of 4.09 cases per 100 cow-months at risk after adjusting for within-herd correlation, although we found some differences after stratification by region (Table 2). LowBMSCC herds in Ontario had the highest overall IRCM in heifers; otherwise, IRCM did not vary between other regions and BMSCC categories. In comparing heifers with multiparous cows, only high-BMSCC herds in On- tario differed in IRCM, with the rate being much higher in multiparous cows (incidence rate ratio $=6.60$ ). No regional differences in pathogen-specific IRCM were present in heifers, and only contagious IRCM was higher in the first 30 DIM in multiparous cows than it was in heifers (Table 3). Incidence rate of CM in heifers and multiparous cows was similar in the first 30 DIM within all BMSCC categories, but when combined was higher in multiparous cows than in heifers (Table 4). Pathogen-specific IRCM did not vary by BMSCC category, nor did it differ between heifers and multiparous cows for any category. In a given herd, although IRCM in multiparous cows was predictive of IRCM in heifers (coefficient $=0.30 ; 95 \%$ CI: $0.10-0.50)$, IRCM in these 2 groups of cows was very poorly correlated $\left(\mathrm{R}^{2}=0.09\right.$; Figure 2).

\section{IMI}

Distribution of pathogens in heifer and multiparous cow samples collected in the first 30 DIM was similar (Table 5). Non-aureus staphylococci were the most commonly isolated group of pathogens in both heifers and multiparous cows (34 and $31 \%$ of total number of samples, respectively). Streptococcus agalactiae was 
Table 1. Distribution of pathogens in clinical mastitis samples from 75 dairy farms in 4 Canadian regions during the first 30 DIM for primiparous $(\mathrm{n}=197)$ and multiparous cattle $(\mathrm{n}=485)$

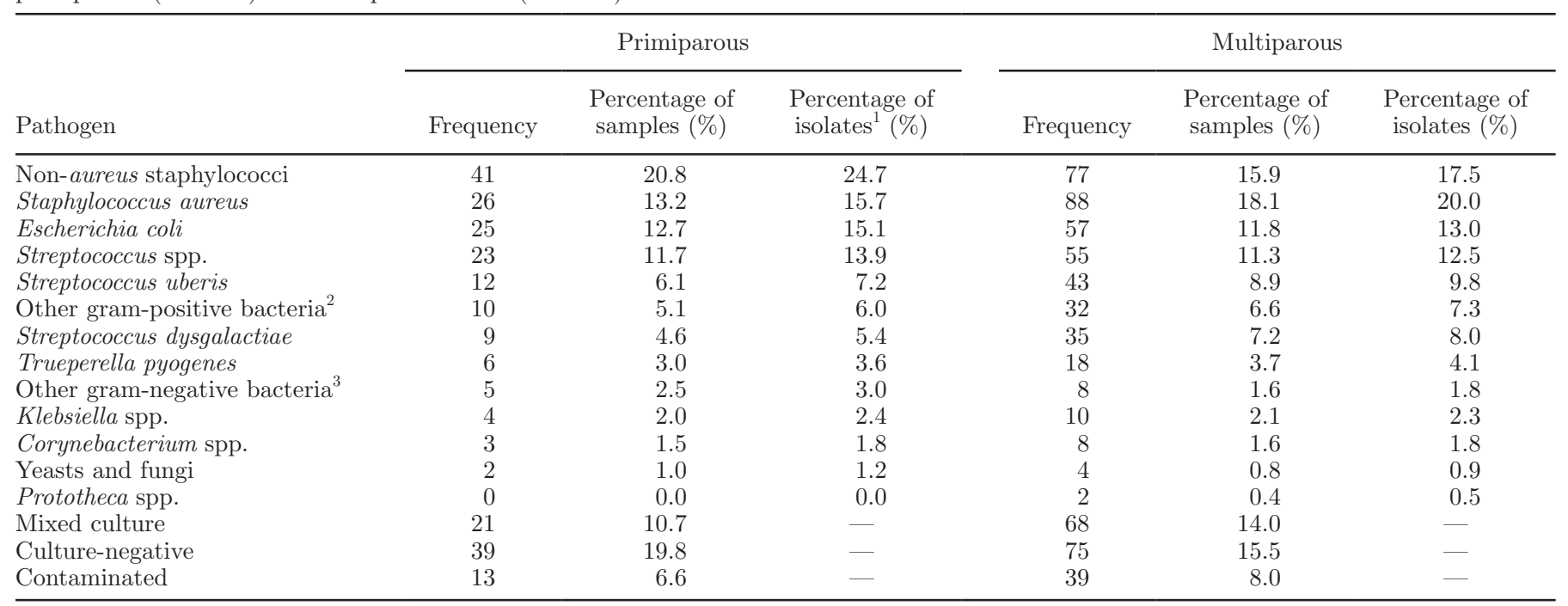

${ }^{1}$ Each sample could contribute up to 2 isolates, whereas samples with $\geq 3$ isolates were considered contaminated. Contaminated and culturenegative samples were not considered when determining percentage of isolates.

${ }^{2}$ Includes Bacillus spp.

${ }^{3}$ Includes Serratia spp., Citrobacter spp., Proteus spp., Salmonella spp., Pseudomonas spp., and Pasteurella multocida.

not isolated from any nonclinical heifers or multiparous cows in the first 30 DIM.

Overall prevalence of IMI was higher in heifers $(33.4 \%)$ than in multiparous cows (25.8\%) and varied among regions (Table 6). Within heifers, NAS IMI prevalence was lowest in Atlantic Canada, whereas IMI by the other pathogens was lowest in Atlantic Canada and
Quebec. The difference in prevalence of IMI between heifers and multiparous cows did not vary regionally, although we noted some differences for the country as a whole. Environmental IMI prevalence was higher $(P=$ $0.04)$ in multiparous cows (3.0\%) compared with heifers $(2.0 \%)$, whereas NAS IMI was more prevalent in heifers $(26.4 \%)$ than in multiparous cows $(18.4 \%)$.

Table 2. Incidence rate of clinical mastitis (IRCM; cases per 100 cow-months at risk) in the first 30 DIM of heifers in Canadian dairy herds

\begin{tabular}{|c|c|c|c|c|c|c|c|}
\hline Item & $\begin{array}{l}\text { No. of } \\
\text { herds }\end{array}$ & $\begin{array}{l}\text { No. clinical } \\
\text { mastitis cases }\end{array}$ & $\begin{array}{l}\text { Total quarter- } \\
\text { months at risk }\end{array}$ & $\begin{array}{l}\text { Mean IRCM } \\
\text { (cases per } 100 \\
\text { cow-months) }\end{array}$ & $95 \% \mathrm{CI}$ & $\begin{array}{l}\text { Rate ratio } \\
\text { compared with } \\
\text { multiparous }\end{array}$ & $95 \%$ CI \\
\hline Low BMSCC $^{1}$ & 14 & 33 & 815 & 4.05 & $2.79-5.68$ & 1.18 & $0.70-1.99$ \\
\hline Ontario & 3 & 19 & 160 & $11.8^{2}$ & $7.12-18.5$ & 0.14 & $0.03-0.69$ \\
\hline Quebec & 3 & 2 & 153 & 1.30 & $0.16-4.69$ & 0.31 & $0.04-2.41$ \\
\hline Atlantic Canada & 5 & 10 & 291 & $3.43^{3}$ & $1.64-6.30$ & 0.39 & $0.07-2.12$ \\
\hline Quebec & 5 & 10 & 241 & 4.13 & $1.98-7.60$ & 2.20 & $0.20-24.72$ \\
\hline Atlantic Canada & 9 & 31 & 690 & 4.49 & $3.05-6.37$ & 1.53 & $0.16-14.4$ \\
\hline High BMSCC ${ }^{1}$ & 30 & 64 & 1,498 & 4.27 & $3.29-5.45$ & 0.82 & $0.42-1.58$ \\
\hline Alberta & 5 & 13 & 334 & $3.89^{3}$ & $2.07-6.64$ & $0.24^{4}$ & $0.04-1.60$ \\
\hline Ontario & 9 & 21 & 517 & 4.05 & $2.51-6.20$ & $6.60^{5}$ & $0.92-47.2$ \\
\hline Quebec & 13 & 25 & 511 & 4.89 & $3.16-7.21$ & 2.35 & $0.22-25.1$ \\
\hline
\end{tabular}

${ }^{1}$ Bulk milk somatic cell count. Low: $<150,000$ cells/mL; medium: 150,000 to 250,000 cells/mL; high: $>250,000$ cells $/ \mathrm{mL}$.

${ }^{2}$ Different $(P<0.05)$ within a BMSCC category, using Alberta herds as a baseline.

${ }^{3}$ Tendency for difference $(0.05<P<0.10)$ within a BMSCC category using Alberta herds as a baseline or from low BMSCC within Alberta.

${ }^{4}$ Tendency for difference $(0.05<P<0.10)$ between heifers and multiparous cows.

${ }^{5}$ Different $(P<0.05)$ between heifers and multiparous cows. 
Table 3. Mean incidence rate of clinical mastitis (cases per 100 cow-days at risk) in the first 30 DIM of heifers and multiparous cows in dairy herds from 4 regions across Canada, stratified by pathogen

\begin{tabular}{lllcccc}
\hline Pathogen type $^{1}$ & Parity & \multicolumn{1}{c}{$\begin{array}{c}\text { Alberta } \\
(95 \% \mathrm{CI})\end{array}$} & $\begin{array}{c}\text { Ontario } \\
(95 \% \mathrm{CI})\end{array}$ & $\begin{array}{c}\text { Quebec } \\
(95 \% \mathrm{CI})\end{array}$ & $\begin{array}{c}\text { Atlantic } \\
(95 \% \mathrm{CI})\end{array}$ \\
\hline Contagious & 1 & $0^{2}$ & $0.84^{3}(0.47-1.50)$ & $1.54(0.85-2.80)$ & $0.63(0.30-1.29)$ & $0.77^{4}(0.52-1.15)$ \\
& $>1$ & $0.91(0.57-1.45)$ & $1.51(0.92-2.46)$ & $1.74(1.14-2.67)$ & $1.34(0.82-2.18)$ & $1.42^{4}(1.10-1.84)$ \\
Environmental & 1 & $1.46(0.60-3.56)$ & $1.61(0.91-2.84)$ & $1.10(0.54-2.25)$ & $1.52(0.87-2.67)$ & $1.46(1.04-2.05)$ \\
& $>1$ & $2.23(1.07-4.66)$ & $1.86(1.02-3.39)$ & $1.21(0.76-1.93)$ & $2.46(1.44-4.18)$ & $1.92(1.40-2.64)$ \\
NAS & 1 & $0.49(0.20-1.22)$ & $1.25^{5}(0.70-2.26)$ & $0.66(0.23-1.91)$ & $0.54(0.20-1.47)$ & $0.82(0.53-1.27)$ \\
& $>1$ & $1.12(0.45-2.75)$ & $1.03(0.54-1.95)$ & $0.58(0.31-1.09)$ & $0.47(0.26-0.86)$ & $0.79(0.54-1.17)$ \\
Other & 1 & $0.12(0.02-0.68)$ & $0.24(0.09-0.62)$ & $0.55(0.21-1.46)$ & $0.36(0.14-0.89)$ & $0.31(0.18-0.53)$ \\
& $>1$ & $0.21(0.09-0.50)$ & $0.48(0.26-0.88)$ & $0.44(0.19-1.00)$ & $0.56(0.28-1.11)$ & $0.45(0.31-0.65)$ \\
Culture-negative & 1 & $0.73(0.22-2.40)$ & $0.84(0.48-1.44)$ & $0.22(0.06-0.85)$ & $1.07(0.46-2.49)$ & $0.75(0.48-1.17)$ \\
& $>1$ & $0.84(0.37-1.89)$ & $0.67(0.37-1.23)$ & $0.29(0.11-0.76)$ & $1.47(0.92-2.35)$ & $0.82(0.58-1.16)$ \\
Overall & 1 & $2.93^{4}(1.36-6.30)$ & $4.66^{3}(3.07-7.07)$ & $4.08(2.53-6.58)$ & $4.12(2.61-6.51)$ & $4.09^{4}(3.18-5.27)$ \\
& $>1$ & $5.24^{4}(3.11-8.82)$ & $5.35(3.39-8.43)$ & $4.12(2.67-6.35)$ & $6.25(4.21-9.28)$ & $5.28^{4}(4.18-6.67)$ \\
\hline
\end{tabular}

${ }^{1}$ Contagious $=$ Staphylococcus aureus, Streptococcus dysgalactiae $;$ environmental = Escherichia coli, Klebsiella spp., Enterobacter spp., Nocardia spp., Prototheca spp., Trueperella pyogenes; NAS = non-aureus staphylococci; other pathogens = other bacteria, yeasts, and fungi.

${ }^{2}$ Incidence and sample size were too low to reliably estimate confidence intervals and rates.

${ }^{3}$ Different $(P<0.05)$ from Alberta within parity.

${ }^{4}$ Different $(P<0.05)$ between heifers and multiparous cows within the same pathogen group and region.

${ }^{5}$ Tendency for difference $(0.05<P<0.10)$ from Alberta within parity.

Overall prevalence of IMI was not different among BMSCC categories, although regional and pathogenspecific differences were present upon stratification (Table 7). Overall IMI prevalence in heifers was highest in high-SCC Alberta herds, but IMI were more prevalent in heifers than in multiparous cows in all regions in high-SCC herds. Contagious pathogen IMI prevalence in heifers was lowest in medium-SCC herds $(1.7 \%)$, and within high-SCC herds was lowest in Ontario and Quebec. Environmental IMI prevalence in heifers did not vary regionally or among BMSCC categories, with a combined adjusted prevalence of $2.0 \%$. Non-aureus staphylococci IMI prevalence was highest in high-SCC Alberta herds (69.3\%), and lowest in low-SCC Atlantic Canada herds (1.9\%). Prevalence of IMI by the other pathogen group varied both within heifers and between heifers and multiparous cows following stratification by region and BMSCC. In highand medium-SCC herds, other IMI prevalence was higher in multiparous cows than heifers. High-SCC heifers from Quebec herds also had the lowest other pathogen group IMI prevalence of all high-SCC herds. Within herds, IMI prevalence in multiparous cows was predictive of IMI prevalence in heifers (coefficient $=$ 0.66 ; $95 \%$ CI: $0.32-1.00)$, and the 2 were not highly correlated $\left(\mathrm{R}^{2}=0.13\right.$; Figure 3$)$.

Table 4. Mean incidence rate of clinical mastitis (per 100 cow-months at risk) in heifers and multiparous cows in the first 30 DIM in Canada stratified by herd bulk milk somatic cell count (BMSCC) and pathogen category

\begin{tabular}{|c|c|c|c|c|c|}
\hline \multirow[b]{2}{*}{ Pathogen type $^{1}$} & \multirow[b]{2}{*}{ Parity } & \multicolumn{3}{|c|}{ BMSCC category $^{2}$} & \multirow[b]{2}{*}{ All Herds $(95 \%$ CI $)$} \\
\hline & & Low $(95 \% \mathrm{CI})$ & Medium $(95 \%$ CI) & High $(95 \%$ CI $)$ & \\
\hline Contagious & $>1$ & $1.40(0.89-2.22)$ & $1.70(1.15-2.50)$ & $1.07(0.72-1.58)$ & $1.42^{3}(1.10-1.84)$ \\
\hline \multirow[t]{2}{*}{ Environmental } & 1 & $1.59(0.88-2.88)$ & $1.22(0.73-2.05)$ & $1.73(0.96-3.15)$ & $1.46(1.04-2.05)$ \\
\hline & $>1$ & $1.40(0.89-2.22)$ & $1.70(1.15-2.50)$ & $1.07(0.72-1.58)$ & $1.92(1.40-2.64)$ \\
\hline NAS & 1 & $0.61(0.20-1.88)$ & $1.04(0.59-1.85)$ & $0.60(0.28-1.30)$ & $0.82(0.53-1.27)$ \\
\hline Other & $>1$ & $0.70(0.37-1.33)$ & $0.81(0.50-1.32)$ & $0.81(0.37-1.80)$ & $0.45(0.31-0.65)$ \\
\hline \multirow[t]{2}{*}{ Culture-negative } & 1 & $0.74(0.30-1.79)$ & $1.00(0.56-1.77)$ & $0.40(0.18-0.91)$ & $0.75(0.48-1.17)$ \\
\hline & $>1$ & $0.26(0.05-1.20)$ & $0.55(0.35-0.87)$ & $0.41(0.22-0.75)$ & $0.82(0.58-1.16)$ \\
\hline \multirow{2}{*}{ Overall } & 1 & $4.05(2.17-7.53)$ & $3.99(2.82-5.65)$ & $4.27(2.72-6.70)$ & $4.09^{3}(3.18-5.27)$ \\
\hline & $>1$ & $4.79(3.53-6.49)$ & $6.34(4.49-8.96)$ & $4.14(2.80-6.10)$ & $5.28^{3}(4.18-6.67)$ \\
\hline
\end{tabular}

${ }^{1}$ Contagious $=$ Staphylococcus aureus, Streptococcus dysgalactiae $;$ environmental = Escherichia coli, Klebsiella spp., Enterobacter spp., Nocardia spp., Prototheca spp., Trueperella pyogenes; NAS = non-aureus staphylococci; other pathogens = other bacteria, yeasts, and fungi.

${ }^{2}$ Low: $<150,000$ cells/mL; medium: 150,000 to 250,000 cells/mL; high: $>250,000$ cells/mL.

${ }^{3}$ Different $(P<0.05)$ between heifers and multiparous cows within the same pathogen group and BMSCC category. 
Table 5. Distribution of mastitis pathogens in milk from clinically normal, randomly selected primiparous $(\mathrm{n}=2,265)$ and multiparous $(\mathrm{n}=$ $6,066)$ lactating cows from 91 dairy farms in 4 Canadian regions in the first 30 DIM

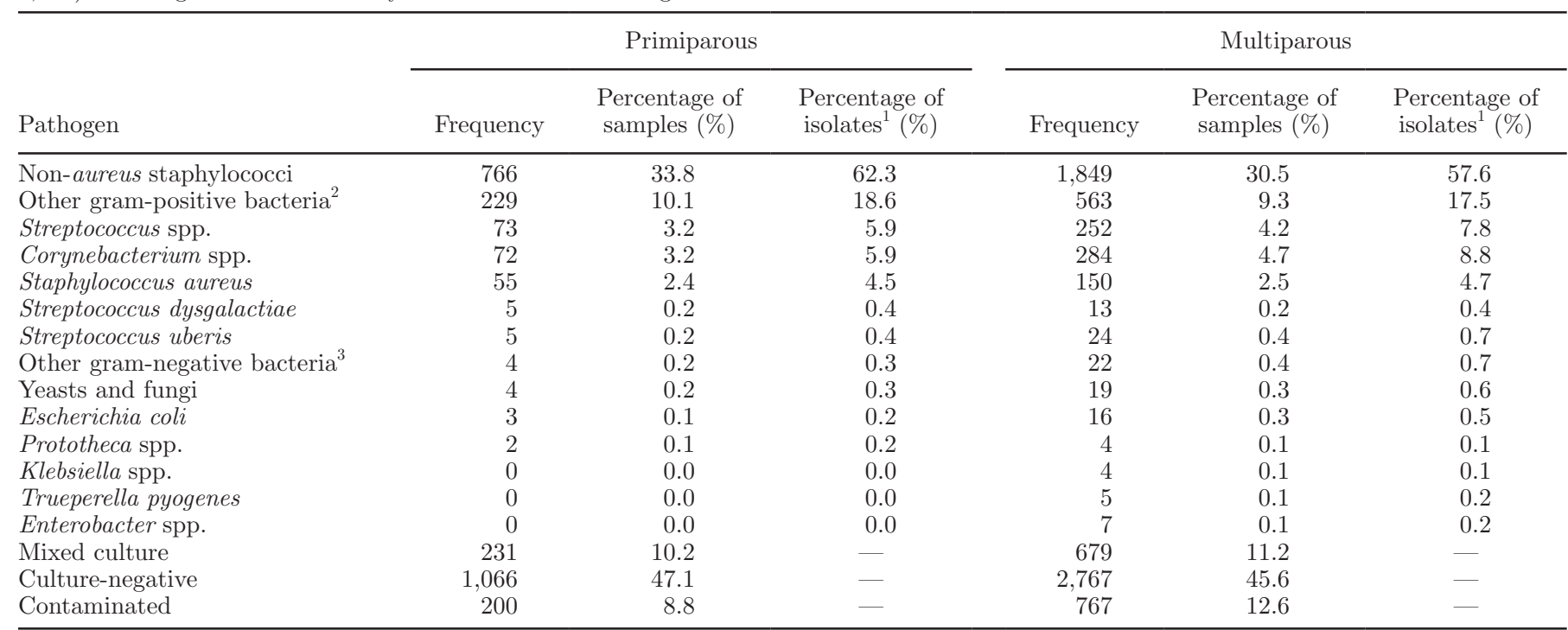

${ }^{1}$ Each sample could contribute up to 2 isolates; samples where $\geq 3$ samples were isolated were considered contaminated. Contaminated and culture-negative samples were not considered when determining percentage of isolates.

${ }^{2}$ Includes Bacillus spp.

${ }^{3}$ Includes Serratia spp., Citrobacter spp., Proteus spp., Salmonella spp., Pseudomonas spp., and Pasteurella multocida.

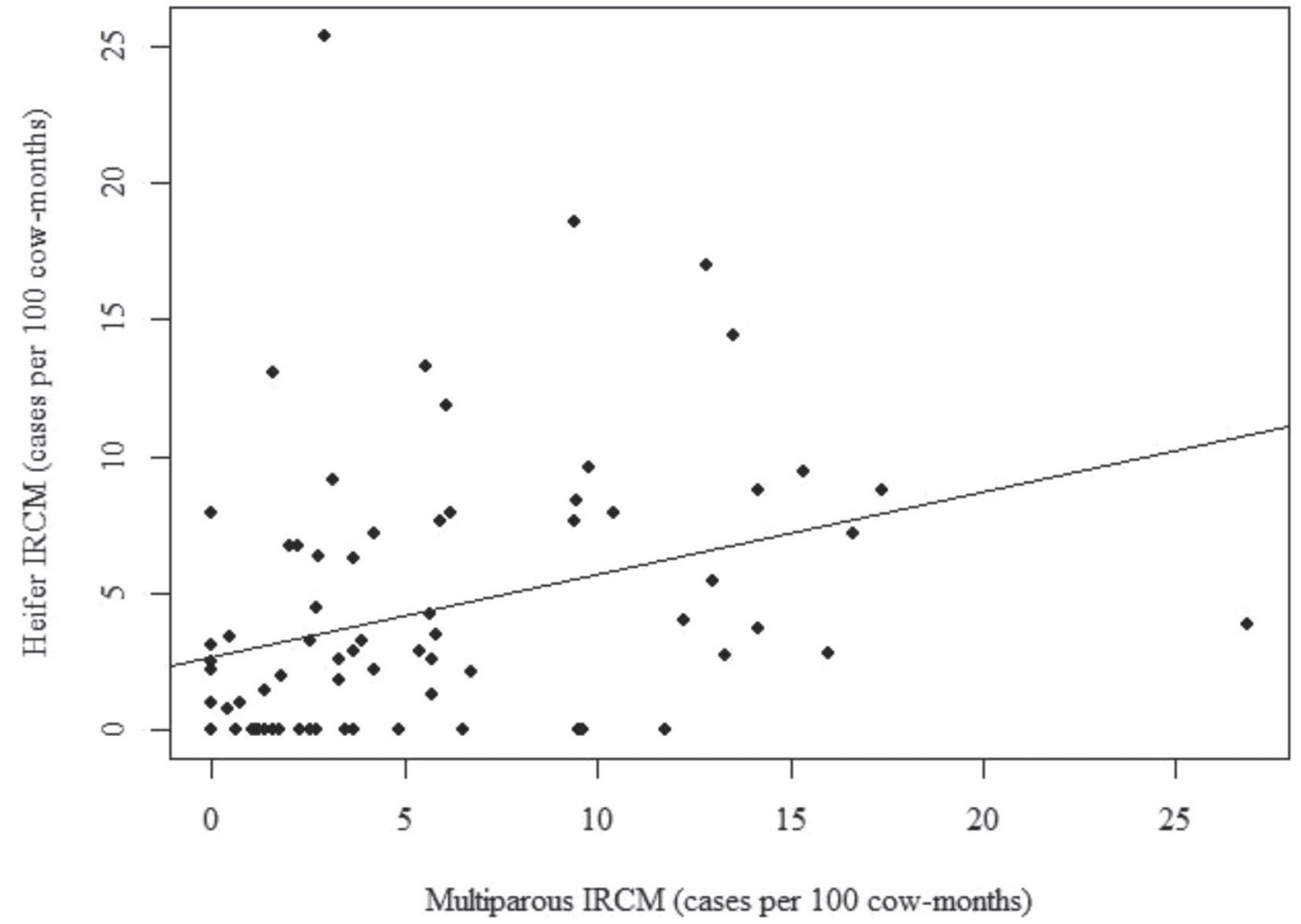

Figure 2. Within-herd comparison of incidence rate of clinical mastitis (IRCM) in the first 30 DIM between primiparous and multiparous cows in 75 Canadian dairy herds. 
Table 6. Quarter-level prevalence (\%) of IMI in heifers and multiparous cows in 4 regions across Canada in the first 30 DIM stratified by pathogen group

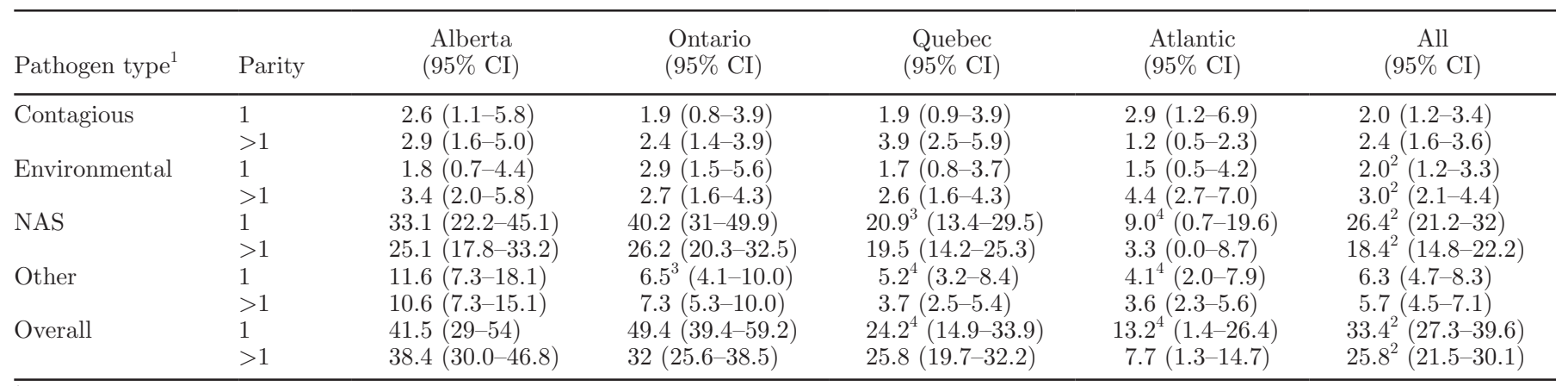

${ }^{1}$ Contagious $=$ Staphylococcus aureus, Streptococcus dysgalactiae , environmental = Escherichia coli, Klebsiella spp., Enterobacter spp., Nocardia spp., Prototheca spp., Trueperella pyogenes; NAS = non-aureus staphylococci; other pathogens = other bacteria, yeasts, and fungi.

${ }^{2}$ Difference $(P<0.05)$ between heifers and multiparous cows within the same pathogen type and region.

${ }^{3}$ Tendency for difference $(0.05<P<0.10)$ from Alberta within same pathogen type and parity.

${ }^{4}$ Different $(P<0.05)$ from Alberta within parity.

\section{SCM}

Prevalence of SCM in heifers was lowest in lowBMSCC herds, with a combined prevalence of $13 \%$ of animals after adjustment for clustering. Furthermore, it increased with increasing BMSCC category, reaching 15 and $20 \%$ in medium- and high-BMSCC herds, respectively. Heifers in Alberta herds had the lowest SCM prevalence at 9.8\%, whereas SCM prevalence was similar among other regions (Table 8). In all regions, SCM was more prevalent in multiparous cows than in heifers. Prevalence of SCM in heifers in the first 30 DIM was positively associated with SCM prevalence in multiparous cows, where heifer SCM prevalence increased $0.29 \%(95 \%$ CI: $0.22-0.35 \%)$ for every $1 \%$ increase in multiparous SCM prevalence $\left(\mathrm{R}^{2}=0.45\right.$; Figure 4).

\section{Within-Herd Associations Between SCM, IMI, and CM}

Overall IRCM was not associated with prevalence of IMI within a herd $\left(\mathrm{R}^{2}=0.01 ; P=0.34\right)$. After

Table 7. Overall and pathogen-specific prevalence (\%) of quarter-level IMI in first-lactation heifers in the first 30 DIM stratified by region and bulk milk SCC (BMSCC) from 91 Canadian dairy herds

\begin{tabular}{|c|c|c|c|c|c|c|}
\hline Item & $\begin{array}{l}\text { No. of } \\
\text { herds }\end{array}$ & $\begin{array}{l}\text { Overall } \\
(95 \% \text { CI })\end{array}$ & $\begin{array}{c}\text { Contagious }^{1} \\
(95 \% \text { CI })\end{array}$ & $\begin{array}{l}\text { Environmental }^{1} \\
\quad(95 \% \mathrm{CI})\end{array}$ & $\begin{array}{c}\mathrm{NAS}^{1} \\
(95 \% \mathrm{CI})\end{array}$ & $\begin{array}{l}\text { Other }^{1} \\
(95 \% \text { CI })\end{array}$ \\
\hline $\mathrm{Low}^{2}$ & 17 & $28.9^{3}(15.6-42.9)$ & $4.6^{3}(2.2-9.2)$ & $1.3(0.4-3.6)$ & $18.4(8.2-30.6)$ & $6.8(3.8-11.9)$ \\
\hline Quebec & 3 & $30.2(5.1-57.6)$ & $3.7(0.6-16.1)$ & $1.1(0-10.6)$ & $15.1(0.0-39.5)$ & $13.0(4.9-30.4)$ \\
\hline Atlantic & 4 & $19.1^{3}(0-44.7)$ & $10.8(3.2-30)$ & $2.0(0.2-11)$ & $1.9^{4}(0.0-21.7)$ & $3.6^{5}(0.9-13.1)$ \\
\hline Medium $^{2}$ & 40 & $31.5(22.6-40.7)$ & $1.2^{4,5}(0.5-2.5)$ & $2.0(1.0-3.9)$ & $28.8(21-37.3)$ & $5.6(3.7-8.4)$ \\
\hline Quebec & 15 & $32.9(15.7-51)$ & $0.1(0-2.9)$ & $4.4(1.5-11.7)$ & $35.0(19.7-52.3)$ & $3.5^{5,6}(1.3-9.1)$ \\
\hline Atlantic & 8 & $9.7(0-28.2)$ & $1.8(0.3-6.5)$ & $1.6(0.3-6.6)$ & $10.6(0.0-26.3)$ & $4.1(1.5-10.3)$ \\
\hline $\mathrm{High}^{2}$ & 35 & $37.8(27.8-48)$ & $2.7^{5}(1.4-5)$ & $2.3(1.1-4.4)$ & $27.7(19.2-37.1)$ & $6.9(4.4-10.5)$ \\
\hline Alberta & 4 & $95.9^{4,5}(70.7-100.0)$ & $7.8(1.7-27.7)$ & $6.3(1.4-23.9)$ & $69.3^{4}(42.1-92.8)$ & $20.8^{5}(8.8-41.7)$ \\
\hline Ontario & 16 & $58.6^{5}(40.5-75.1)$ & $2.1^{4}(0.5-6.9)$ & $6.2(2.4-15.2)$ & $41.6(25.6-58.8)$ & $7.5^{3}(3.5-15.4)$ \\
\hline Quebec & 9 & $18.9^{5}(8.1-30.5)$ & $3.1^{4}(1.4-6.5)$ & $1.1(0.3-3.1)$ & $16.5(8.0-26.7)$ & $4.8^{4,5}(2.5-8.8)$ \\
\hline Atlantic & 5 & $15.9^{4,5}(0-42.2)$ & $1.6^{3,6}(0.1-10)$ & $1.2(0.0-10.1)$ & $14.2(0.0-37.7)$ & $5.1(1.5-16.4)$ \\
\hline
\end{tabular}

${ }^{1}$ Contagious = Staphylococcus aureus, Streptococcus dysgalactiae , environmental = Escherichia coli, Klebsiella spp., Enterobacter spp., Nocardia spp., Prototheca spp., Trueperella pyogenes; NAS = non-aureus staphylococci; other pathogens = other bacteria, yeasts, and fungi.

${ }^{2}$ Low: $<150,000$ cells/mL; medium: 150,000 to 250,000 cells $/ \mathrm{mL}$; high: $>250,000$ cells $/ \mathrm{mL}$.

${ }^{3}$ Tendency for difference $(0.05<P<0.10)$ between heifers and multiparous cows within the same BMSCC category and region.

${ }^{4}$ Different $(P<0.05)$ from Alberta herds within BMSCC category and heifers, or from low BMSCC herds within heifers.

${ }^{5}$ Different $(P<0.05)$ between heifers and multiparous cows within the same BMSCC category and region.

${ }^{6}$ Tendency for difference $(0.05<P<0.10)$ from Alberta herds within BMSCC category and heifers, or from low BMSCC herds within heifers. 


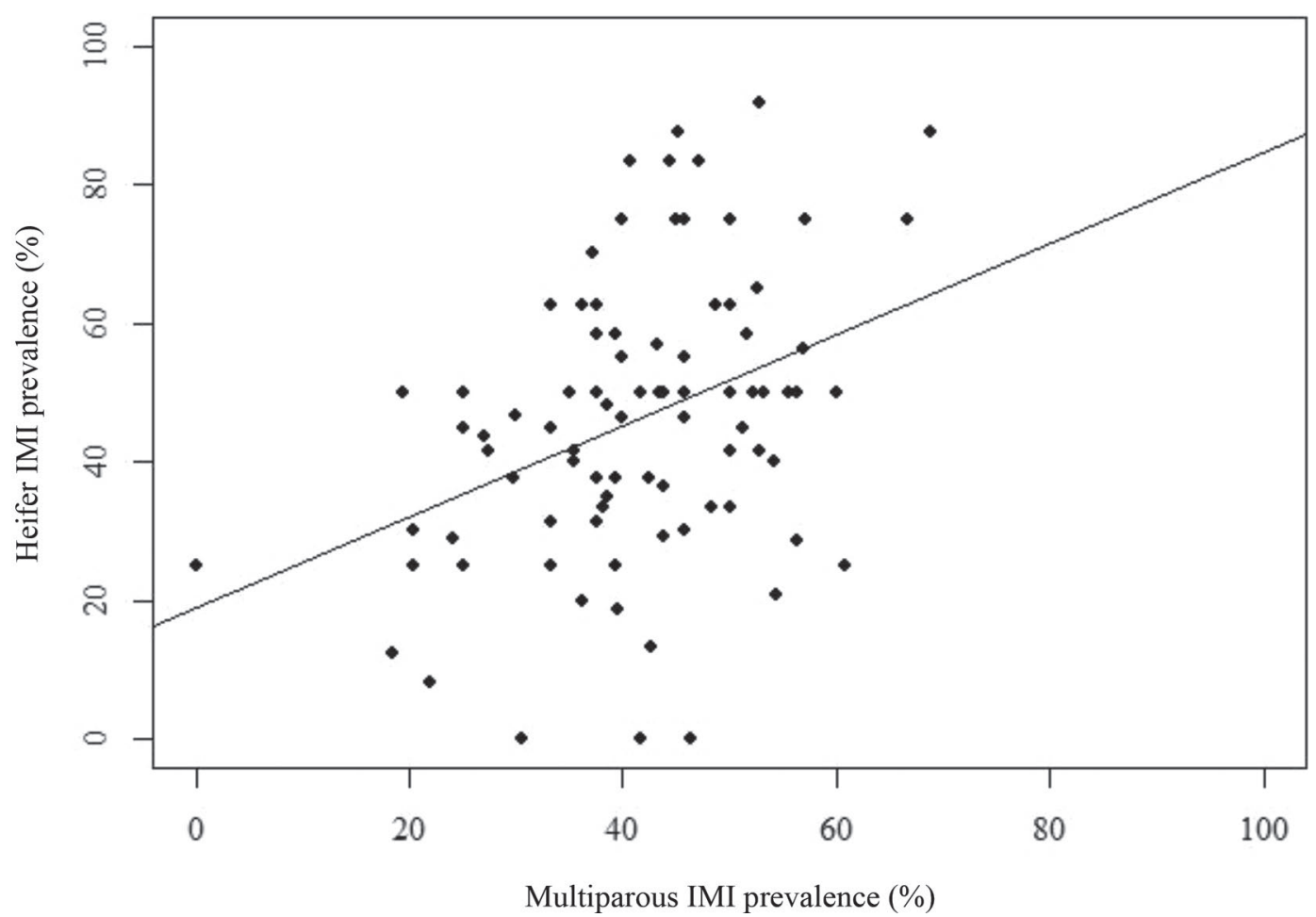

Figure 3. Within-herd comparison of the prevalence of IMI in the first 30 DIM between primiparous and multiparous cows in 75 Canadian dairy herds $\left(\mathrm{R}^{2}=0.13\right)$.

stratification by pathogen type, the correlation was even lower between IRCM and IMI $\left(\mathrm{R}^{2}<0.01\right.$ for all pathogen types: contagious, environmental, NAS, and other). Subclinical mastitis prevalence was also very poorly correlated with both overall IMI prevalence $\left(\mathrm{R}^{2}\right.$ $=0.002)$ and IRCM $\left(\mathrm{R}^{2}=0.001\right)$. Pathogen-specific correlations between IMI prevalence or IRCM and

Table 8. Quarter-level prevalence of subclinical mastitis (SCC $>200,000$ cells $/ \mathrm{mL}$ ) in herds across 4 regions in Canada

\begin{tabular}{lccc}
\hline Region & $\begin{array}{c}\text { No. of } \\
\text { herds }\end{array}$ & Parity & Prevalence \\
\hline Alberta & 27 & 1 & $9.8^{1}(7.8-12.3)$ \\
& & $>1$ & $17.5^{1}(14.7-20.7)$ \\
Ontario & 29 & 1 & $15.6^{1,2}(12.7-19)$ \\
Quebec & & $>1$ & $18.2^{1}(15.3-21.4)$ \\
& 27 & 1 & $13.2^{2,3}(11-15.7)$ \\
Atlantic & 17 & 1 & $18.2^{3}(15.8-20.9)$ \\
Total & & $>1$ & $15.9^{1,2}(13.2-19.1)$ \\
& 91 & 1 & $15.9^{1}(13.8-18.3)$ \\
& & $>1$ & $13.6^{1}(12.3-15.1)$ \\
\hline
\end{tabular}

${ }^{1}$ Different $(P<0.05)$ between heifers and multiparous cows within a region.

${ }^{2}$ Different $(P<0.05)$ within a parity using Alberta herds as a baseline. ${ }^{3}$ Tendency for difference $(0.05<P<0.10)$ between heifers and multiparous cows within a region.
SCM prevalence were also very low $\left(\mathrm{R}^{2}<0.01\right.$ for all pathogen types).

\section{DISCUSSION}

The primary aim of our study was to quantify occurrence of udder health problems in primiparous heifers on Canadian dairy farms in the early postcalving period. The incidence of clinical mastitis in dairy herds in Canada and its regional variation are well described (Olde Riekerink et al., 2008); however, no study has focused on CM, IMI, or SCM in primiparous heifers. Rates of disease in multiparous cows in our study were estimated only to enable comparisons with disease rates in primiparous heifers. Describing regional variation and differences from multiparous cows will inform decisions by provincial dairy marketing boards regarding targets for improvement, research, and priorities in disease management. Although cumulative IRCM was higher in multiparous cows than heifers during the first 30 DIM, IRCM was higher in heifers than multiparous cows in the days immediately after calving. Only IRCM by contagious pathogens was higher in multiparous cows than in heifers in the first 30 DIM, whereas all other pathogen-specific rates were similar between the 2 groups. Overall prevalence of IMI in the first 30 
DIM was higher in heifers than in multiparous cows. Pathogen-specific differences were only present upon stratification by region and BMSCC. Prevalence of SCM was higher in multiparous cows than heifers in all BMSCC categories and regions. Based on similarities in postcalving disease rates between heifers and multiparous cows, we concluded that targeted management of heifers should be as much of a priority as mastitis management for the rest of the herd.

Comparisons of disease rates with other studies is difficult, as units of measurement for disease depend on the objectives of the study. The present study used the first 30 DIM to understand the disease burden in heifers before they have been exposed to the lactating herd for a long interval. However, shorter observation intervals relative to the lactation require different units for animals at risk (e.g., 100 cow-years at risk versus 10,000 cow-days at risk) to enable sufficient resolution to highlight differences. Bearing that in mind, indirect comparisons can be made by crudely extrapolating results (e.g., a daily incidence of 1 per 100 would translate to an approximate cumulative monthly incidence of 30 per 100). Regardless, care must be taken because such comparisons do not consider changes in disease dynamics throughout lactation.
The 30 DIM IRCM at animal level was 4.09 cases per 100 cows at risk. This is comparable to results published by Elghafghuf et al. (2014), who used the same data set from the CBMQRN study in 2007 and 2008 that reported a yearly incidence in heifers of 21.3 per 100 cow-years at risk with monthly IRCM decreasing after a peak hazard of CM in the first 13 DIM. Taking 4 times this monthly IRCM (approximately 16\%) shows consistency with Parker et al. (2007), who reported $13.6 \%$ cumulative IRCM during the first 4 mo of lactation in dairy heifers in New Zealand. In an earlier study in Finland, IRCM in heifers was higher than the present study's 30-DIM IRCM at $4.4 \%$ in the only the first week of lactation (Myllys and Rautala, 1995). Barkema et al. (1998) reported a lower mean IRCM in heifers of 4.38 cases per 10,000 cow-days at risk for the course of the lactation (approximately 1.3 cases per $100 \mathrm{cow}-$ months at risk), noting that $>30 \%$ of cases occurred in the first $14 \mathrm{~d}$ of lactation.

During the first day of lactation, overall IRCM was much higher in first-calving heifers than in multiparous cows, consistent with other reports (Barkema et al., 1998; Compton et al., 2007). After the first few DIM, heifer IRCM decreased to rates similar to multiparous cow IRCM, which was also demonstrated by Barkema

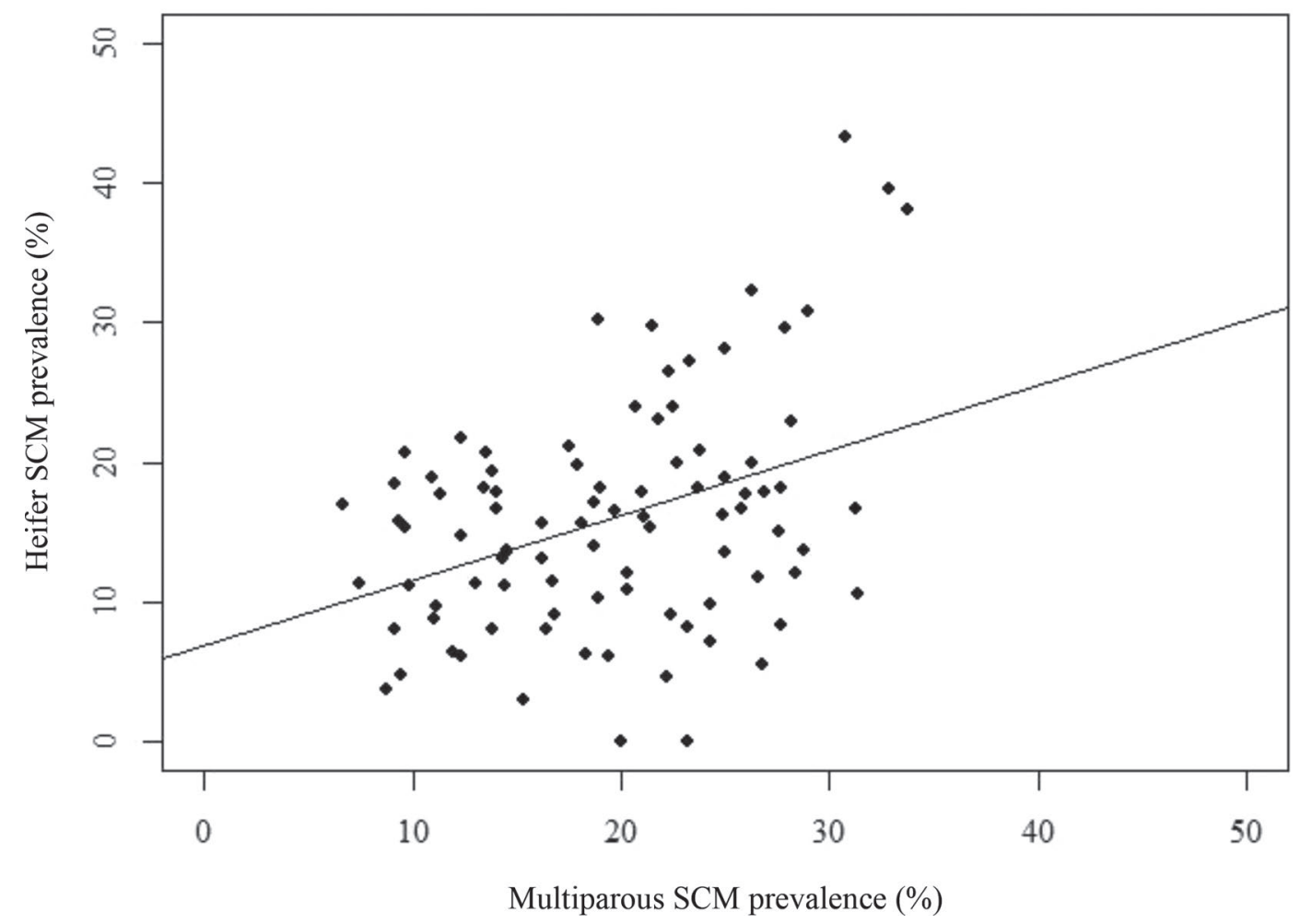

Figure 4. Within-herd comparison of the prevalence of subclinical mastitis (SCM) in the first 30 DIM between primiparous and multiparous cows in 91 Canadian dairy herds $\left(\mathrm{R}^{2}=0.45\right)$. 
et al. (1998). In contrast, Compton et al. (2007) reported that heifer IRCM remained consistently higher than in older cow IRCM, even after the first week of lactation. In the present study, overall IRCM during the first 30 DIM was slightly lower in heifers (4.09 cases per 100 cow-months at risk) than in multiparous cows (5.28 cases per 100 cow-months at risk), consistent with results from Belgium (Verbeke et al., 2014), Estonia (Kalmus et al., 2006), and Sweden (Persson Waller et al., 2009).

Pathogen distribution from CM highlighted interesting differences between the present study and other studies. In heifers with CM, NAS were the most commonly isolated pathogens, whereas in multiparous cows Staph. aureus was the most commonly isolated pathogen. In Belgium, Strep. uberis and E. coli were the most commonly isolated pathogens from cases of clinical mastitis in heifers (Verbeke et al., 2014); Strep. uberis was by far the most commonly isolated pathogen in New Zealand (Compton et al., 2007); Staph. aureus, Strep. dysgalactiae, and E. coli were most common in Sweden (Persson Waller et al., 2009); E. coli and CNS were most common in China (Yang et al., 2015); Staph. aureus and E. coli were most common in the Netherlands (Barkema et al., 1998); and E. coli and Strep. uberis were most common in Estonia (Kalmus et al., 2006). In multiparous cows, Staph. aureus and E. coli were the most frequently isolated pathogen from clinical mastitis cases (Verbeke et al., 2014; Levison et al., 2016). In general, environmental pathogens are more commonly isolated from heifers than from multiparous cows with CM, whereas Staph. aureus is typically associated with mastitis in multiparous cows and is occasionally isolated from heifers. The high number of NAS isolated from heifer CM samples (unlike many previous studies) highlighted their role in udder health, especially for Canadian herds. In the present study, only contagious IRCM was higher in multiparous cows than heifers in the first 30 DIM, whereas all others were very similar, suggesting that contagious pathogens were driving the higher IRCM in multiparous cows. Interestingly, IRCM in heifers did not vary among regions, although a previous study in Canada demonstrated significant regional variation in multiparous cows (Olde Riekerink et al., 2008), attributed partially to regional differences in housing types and climate. As heifer housing in Canada typically differs from housing of multiparous cows, that difference in housing type may not be as important in young stock. Low within-herd correlations of IRCM between heifers and multiparous cows may have been due to differences in management; although, as sample sizes for this comparison were low, the analysis had limited reliability and should be interpreted with caution.
Overall prevalence of IMI in our study was similar to those conducted in other countries, although variation among those studies exists as well. Early-lactation IMI prevalence was as low as $22 \%$ in New Zealand (Compton et al., 2007) and approximately $30 \%$ in Belgium and Denmark (Aarestrup and Jensen, 1997; Piepers et al., 2009). Overall IMI prevalence of $34 \%$ of quarters in heifers was reported in our study, which seemed slightly higher than previous studies (although animal-level prevalence may be more similar), but still lower than a prevalence of $57 \%$ reported in Brazil (da Costa et al., 1996). Comparing IMI prevalence between studies can be difficult due to differences in the case definition of IMI after culturing, with different sensitivities and specificities (Dohoo et al., 2011a,b) that can lead to effects on analysis due to misclassification (Dufour et al., 2012). In our study, a diagnosis of IMI diagnosis was a pathogen-specific case definition, based on a single sample with the highest sensitivities and specificities (Dohoo et al., 2011b), followed by correction of prevalence estimates using those values. Overall prevalence of IMI in the first 30 DIM was higher in heifers than in multiparous cows (34 vs. 26\%).

Pathogen distribution in heifer IMI was similar to previously described research. Non-aureus staphylococci were the most commonly isolated pathogens from milk samples, being isolated from $34 \%$ of samples. Studies in Brazil, Denmark, New Zealand, Belgium, and the United States reported prevalence of CNS IMI at 49, 14, 10, 10, and 9\%, respectively (da Costa et al., 1996; Aarestrup and Jensen, 1997; Compton et al., 2007; Piepers et al., 2009; Rowbotham and Ruegg, 2016). Overall prevalence of NAS IMI in heifers was $26 \%$, although, when using a Bayesian framework, adjusted CNS IMI prevalence was 43\% (Dufour et al., 2012). This difference may be attributed to different adjustment methods and different study populations (heifers in the present study versus both heifers and multiparous cows in Dufour et al., 2012). Regional differences in IMI prevalence were present for only NAS and other pathogens, with Atlantic Canada having the lowest prevalence of both. Differences in regional climate and housing types, and other management practices that were not captured in our study, may have contributed to differences in bacterial species present in the environment. We observed no variation in prevalence of IMI by any pathogen type across BMSCC categories without further stratification by region. In high-BMSCC herds, overall IMI was more prevalent in multiparous cows in all regions. Interestingly, contagious pathogen prevalence in heifers was actually highest in low-SCC herds, but was not different from prevalence in multiparous cows. In both high- and medium-SCC farms, 
contagious IMI prevalence was much higher in multiparous cows. These observations were counterintuitive, as proper milking management practices should decrease prevalence of contagious pathogens and BMSCC.

Low within-herd correlation of heifer IMI prevalence and older cow IMI prevalence may be reflective of the different environment and pathogens the animals are exposed to before calving. Again, a low sample size makes this comparison fairly crude, and results should be interpreted with caution.

The dynamics of immune response measured by SCC differed through lactation and around clinical cases of mastitis in heifers and multiparous cows (de Haas et al., 2002, 2004). Indeed, when infected by Staph. aureus, the resultant SCC elevation increases with lactation, whereas SCC in uninfected animals does not vary by lactation (Sheldrake et al., 1983). When the goal of SCC measurement is to act as an analog for IMI, a decreased threshold of 150,000 cells/mL only offers a $5 \%$ increase in sensitivity in all cattle, with a difference in predicted IMI prevalence of 3\% (Petzer et al., 2017). Despite these differences and the range in thresholds used in the literature, healthy cow SCC rarely exceeds 70,000 cells $/ \mathrm{mL}$, and a threshold of 200,000 cells $/ \mathrm{mL}$ has optimal sensitivity and specificity as an indicator for IMI in all cattle (Schukken et al., 2003; Lam et al., 2009). Without estimates of sensitivity and specificity for the use of SCC as an indicator for IMI specifically in heifers, the threshold of 200,000 cells/mL for classifying SCM is the best option.

Subclinical mastitis was present in $13.6 \%$ of heifers tested in the first 30 DIM, and was consistent regionally, except for in Alberta where it was only 9.8\%. In a previous study (Santman-Berends et al., 2012), prevalence of SCM in heifers was $26 \%$ in the first 100 DIM, perhaps due to a longer observation period. Rowbotham and Ruegg (2016) estimated SCM in heifers to be present in $31 \%$ of quarters over the course of the first year in lactation. Comparisons with previous research in heifers was difficult, due to different case definitions for subclinical mastitis (the current study used SCC $\geq 200,000$ cells $/ \mathrm{mL}$ ) and follow-up periods, although overall results seemed consistent. Withinherd correlation of SCM prevalence between heifers and multiparous cows was higher than it was for IRCM and IMI. Sample sizes for SCM prevalence were much higher than the other 2 parameters, suggesting that correlations in the others may not have been significant due to lack of power.

Measures of disease had very low correlation with each other within a herd. Although the relatively low incidence of CM made the comparison underpowered compared with more common diseases, IMI were also very poorly correlated with subclinical mastitis. Preva- lence of IMI is associated with BMSCC (Eberhart et al., 1982; Wilson et al., 1997) and is not consistent with the findings of the current study, where IMI prevalence did not vary by BMSCC category. This may be a result of categorizing BMSCC using ranges rather than using raw BMSCC values, which would allow for a more powerful regression model. When assessing elevated SCC prevalence at the animal level rather than using BMSCC as an analog, missing high-SCC animals during random selection would strongly affect the estimate. Separation of milk from high-SCC cows would remove their contribution to the BMSCC, resulting in the herd being classified into a lower category. No studies have been done to quantify the use of this practice in Canadian dairy farms.

Regional differences in disease rates across Canada may be affected by the range in climate conditions across the country, as well as diversity in housing and management practices. Previous research has focused on investigating regional variations in milking practices (Belage et al., 2017) and rates of CM (Olde Riekerink et al., 2008), whereas regional statistics on housing and milking systems are publicly available (Canadian Dairy Information Centre, 2016, 2017). Surveys that accompanied the sampling for the current study (Reyher et al., 2011) investigated risk factors for mastitis using questions about the milking herd, the milking process, and calving management. Despite the availability of this information and abundance of research, no data were collected on the management of nonlactating heifers. Without prior exposure to the lactating herd, exposure to risk factors for early postcalving mastitis in heifers is determined by their precalving management. Precalving management of heifers in Canada has not been reported, nor is information on their housing available from federal or provincial organizations. De Vliegher et al. (2004) reported associations of AI methods, udder clipping, fly control, deworming, commingling with dry cows, and feed management with increased risks of having elevated SCC in heifers. Given regional differences in udder health parameters of heifers, understanding the origin of these differences is a crucial gap in knowledge in the Canadian dairy industry.

\section{CONCLUSIONS}

Similar to previous studies, heifer IRCM was higher than in multiparous cows in the first day after calving but lower thereafter in heifers than in multiparous cows. No regional variation in IRCM by any pathogen was observed, nor did we note any major difference among BMSCC categories. Prevalence of IMI in Canada was similar to described in other studies, highlighting the importance of the issue. Overall prevalence of IMI was 
higher in heifers than in older cows, with some pathogen-specific differences regionally and across BMSCC. Subclinical mastitis prevalence in heifers was consistent across most of Canada and was lower than SCM prevalence in multiparous cows. Based on similarities in disease rates between heifers and multiparous cows in the early postcalving period, management practices and mastitis research in the Canadian dairy industry must include the precalving period for heifers.

\section{ACKNOWLEDGMENTS}

This study was supported by the Industrial Research Chair in Infectious Diseases of Dairy Cattle, funded by Canada's Natural Sciences and Engineering Research Council (NSERC) Industrial Research Chair Program (Ottawa, ON, Canada), with industry contributions from Alberta Milk (Edmonton, AB, Canada), the Dairy Farmers of Canada (Ottawa, ON, Canada), Westgen Endowment Fund (Milner, BC, Canada), the BC Dairy Association (Burnaby, BC, Canada), Canadian Dairy Network (Guelph, ON, Canada), CanWest DHI (Guelph, ON, Canada), and Dairy Farmers of Manitoba (Winnipeg, MB, Canada). The first author was supported by a NSERC CREATE in Milk Quality Graduate student scholarship from the Canadian Bovine Mastitis and Milk Quality Research Network (Saint-Hyacinthe, QC, Canada).

\section{REFERENCES}

Aarestrup, F. M., and N. E. Jensen. 1997. Prevalence and duration of intramammary infection in Danish heifers during the peripartum period. J. Dairy Sci. 80:307-312. https://doi.org/10.3168/jds .S0022-0302(97)75939-3.

Barkema, H. W., Y. H. Schukken, T. J. G. M. Lam, M. L. Beiboer, H Wilmink, G. Benedictus, and A. Brand. 1998. Incidence of clinical mastitis in dairy herds grouped in three categories by bulk milk somatic cell counts. J. Dairy Sci. 81:411-419. https://doi.org/10 .3168/jds.S0022-0302(98)75591-2.

Bates, D., M. Maechler, B. Bolker, and S. Walker. 2015. Fitting linear mixed-effects models using lme4. J. Stat. Softw. 67:1-48. https:// doi.org/10.18637/jss.v067.i01.

Belage, E., S. Dufour, C. Bauman, A. Jones-Bitton, and D. Kelton. 2017. The Canadian National Dairy Study 2015: Adoption of milking practices in Canadian dairy herds. J. Dairy Sci. 100:3839-3849. https://doi.org/10.3168/jds.2016-12187.

Betensky, R. A., J. A. Talcott, and J. C. Weeks. 2000. Binary data with two, non-nested sources of clustering: an analysis of physician recommendations for early prostate cancer treatment. Biostatistics 1:219-230. https://doi.org/10.1093/biostatistics/1.2.219.

Canadian Dairy Information Centre. 2016. Types of dairy barns. Accessed Nov. 18, 2017. http://www.dairyinfo.gc.ca/index_e.php?s1 $=$ dff-fcil\&s $2=$ farm-ferme\&s $3=$ db-el.

Canadian Dairy Information Centre. 2017. Number of farms, dairy cows and heifers. Accessed Nov. 18, 2017. http://www.dairyinfo.gc .ca/index_e.php?s1=dff-fcil\&s $2=$ farm-ferme\&s $3=$ nb.

Compton, C. W. R., C. Heuer, K. Parker, and S. McDougall. 2007. Epidemiology of mastitis in pasture-grazed peripartum dairy heifers and its effects on productivity. J. Dairy Sci. 90:4157-4170. https://doi.org/10.3168/jds.2006-880. da Costa, E. O., P. A. Melville, A. R. Ribeiro, E. Watanabe, F. C. Viani, and C. R. White. 1996. Prevalence of intramammary infections in primigravid Brazilian dairy heifers. Prev. Vet. Med. 29:151-155. https://doi.org/10.1016/S0167-5877(96)01072-0.

de Haas, Y., H. W. Barkema, and R. F. Veerkamp. 2002. The effect of pathogen-specific clinical mastitis on the lactation curve for somatic cell count. J. Dairy Sci. 85:1314-1323. https://doi.org/10 .3168/jds.S0022-0302(02)74196-9.

de Haas, Y., R. F. Veerkamp, H. W. Barkema, Y. T. Gröhn, and Y. H. Schukken. 2004. Associations between pathogen-specific cases of clinical mastitis and somatic cell count patterns. J. Dairy Sci. 87:95-105. https://doi.org/10.3168/jds.S0022-0302(04)73146-X.

De Vliegher, S., L. K. Fox, S. Piepers, S. McDougall, and H. W. Barkema. 2012. Invited review: Mastitis in dairy heifers: Nature of the disease, potential impact, prevention, and control. J. Dairy Sci 95:1025-1040. https://doi.org/10.3168/jds.2010-4074.

De Vliegher, S., H. Laevens, H. W. Barkema, I. R. Dohoo, H. Stryhn, G. Opsomer, and A. de Kruif. 2004. Management practices and heifer characteristics associated with early lactation somatic cell count of Belgian dairy heifers. J. Dairy Sci. 87:937-947. https:// doi.org/10.3168/jds.S0022-0302(04)73238-5.

Dohoo, I., S. Andersen, R. Dingwell, K. Hand, D. Kelton, K. Leslie, Y Schukken, and S. Godden. 2011a. Diagnosing intramammary infections: comparison of multiple versus single quarter milk samples for the identification of intramammary infections in lactating dairy cows. J. Dairy Sci. 94:5515-5522. https://doi.org/10.3168/jds.2011 -4486 .

Dohoo, I. R., J. Smith, S. Andersen, D. F. Kelton, and S. Godden. 2011b. Diagnosing intramammary infections: evaluation of definitions based on a single milk sample. J. Dairy Sci. 94:250-261. https://doi.org/10.3168/jds.2010-3559.

Dohoo, I. R., H. Stryhn, and S. W. Martin. 2014. Veterinary Epidemiologic Research. VER Inc., Charlottetown, PEI, Canada.

Dufour, S., I. R. Dohoo, H. W. Barkema, L. Descôteaux, T. J. Devries, K. K. Reyher, J.-P. Roy, and D. T. Scholl. 2012. Epidemiology of coagulase-negative staphylococci intramammary infection in dairy cattle and the effect of bacteriological culture misclassification. J Dairy Sci. 95:3110-3124. https://doi.org/10.3168/jds.2011-5164.

Dufour, S., A. Le Plain, K. Reyher, and D. Scholl. 2011. Clinical mastitis: What have we measured? Canadian Bovine Mastitis Research Network Annual Meeting. Montreal, QC, Canada.

Eberhart, R. J., L. J. Hutchinson, and S. B. Spencer. 1982. Relationships of bulk tank somatic cell counts to prevalence of intramammary infection and to indices of herd production. J. Food Prot. 45:1125-1128.

Elghafghuf, A., S. Dufour, K. Reyher, I. Dohoo, and H. Stryhn. 2014. Survival analysis of clinical mastitis data using a nested frailty Cox model fit as a mixed-effects Poisson model. Prev. Vet. Med. 117:456-468. https://doi.org/10.1016/j.prevetmed.2014.09.013.

Gröhn, Y. T., D. J. Wilson, R. N. González, J. A. Hertl, H. Schulte, G. Bennett, and Y. H. Schukken. 2004. Effect of pathogen-specific clinical mastitis on milk yield in dairy cows. J. Dairy Sci. 87:3358 3374. https://doi.org/10.3168/jds.S0022-0302(04)73472-4.

Halekoh. U., S. Højsgaard, and J. Yan. 2006. The R package geepack for generalized estimating equations. J. Stat. Softw. 15:1-11. https://doi.org/10.18637/jss.v015.i02.

Hogan, J. S., R. N. Gonzalez, R. J. Harmon, S. C. Nickerson, S. P. Oliver, J. W. Pankey, and K. L. Smith. 1999. Laboratory Handbook on Bovine Mastitis. National Mastitis Council, Madison, WI..

Kalmus, P., A. Viltrop, B. Aasmäe, and K. Kask. 2006. Occurrence of clinical mastitis in primiparous Estonian dairy cows in different housing conditions. Acta Vet. Scand. 48:21. https://doi.org/10 .1186/1751-0147-48-21.

Lam, T., R. Olde Riekerink, O. Sampimon, and H. Smith. 2009. Mastitis diagnostics and performance monitoring: A practical approach. Ir. Vet. J. 62:S34-39.

Levison, L. J., E. K. Miller-Cushon, A. L. Tucker, R. Bergeron, K. E. Leslie, H. W. Barkema, and T. J. DeVries. 2016. Incidence rate of pathogen-specific clinical mastitis on conventional and organic Canadian dairy farms. J. Dairy Sci. 99:1341-1350. https://doi.org/10 $.3168 /$ jds.2015-9809. 
McNutt, L.-A., C. Wu, X. Xue, and J. P. Hafner. 2003. Estimating the relative risk in cohort studies and clinical trials of common outcomes. Am. J. Epidemiol. 157:940-943. https://doi.org/10.1093/ aje/kwg074.

Moosavi, M., A. Mirzaei, M. Ghavami, and A. Tamadon. 2014. Relationship between season, lactation number and incidence of clinical mastitis in different stages of lactation in a Holstein dairy farm. Vet. Res. Forum 5:13-19.

Myllys, V., and H. Rautala. 1995. Characterization of clinical mastitis in primiparous heifers. J. Dairy Sci. 78:538-545. https://doi.org/ 10.3168/jds.S0022-0302(95)76664-4.

Olde Riekerink, R. G. M., H. W. Barkema, D. F. Kelton, and D. T. Scholl. 2008. Incidence rate of clinical mastitis on Canadian dairy farms. J. Dairy Sci. 91:1366-1377. https://doi.org/10.3168/ jds.2007-0757.

Pankey, J. W., P. A. Drechsler, and E. E. Wildman. 1991. Mastitis prevalence in primigravid heifers at parturition. J. Dairy Sci. 74:1550-1552. https://doi.org/10.3168/jds.S0022-0302(91)78316 $-1$.

Parker, K., C. Compton, F. Anniss, A. Weir, and S. McDougall. 2007. Management of dairy heifers and its relationships with the incidence of clinical mastitis. N. Z. Vet. J. 55:208-216. https://doi .org/10.1080/00480169.2007.36770.

Persson Waller, K., B. Bengtsson, A. Lindberg, A. Nyman, and H. Ericsson Unnerstad. 2009. Incidence of mastitis and bacterial findings at clinical mastitis in Swedish primiparous cows-Influence of breed and stage of lactation. Vet. Microbiol. 134:89-94. https:// doi.org/10.1016/j.vetmic.2008.09.004.

Petzer, I.-M., J. Karzis, E.F. Donkin, E.C. Webb, and E.M.C. Etter. 2017. Somatic cell count thresholds in composite and quarter milk samples as indicator of bovine intramammary infection status. Onderstepoort J. Vet. Res. 84:1-10. https://doi.org/10.4102/ojvr .v84i1.1269.

Piepers, S., S. De Vliegher, A. De Kruif, G. Opsomer, and H. W. Barkema. 2009. Impact of intramammary infections in dairy heifers on future udder health, milk production, and culling. Vet. Microbiol. 134:113-120. https://doi.org/10.1016/j.vetmic.2008.09 .017 .

R Core Team. 2017. R: A language and environment for statistical computing. R Foundation for Statistical Computing, Vienna, Austria. https://www.R-project.org/.

Reyher, K. K., S. Dufour, H. W. Barkema, L. Des Côteaux, T. J. DeVries, I. R. Dohoo, G. P. Keefe, J.-P. Roy, and D. T. Scholl.
2011. The National Cohort of Dairy Farms - A data collection platform for mastitis research in Canada. J. Dairy Sci. 94:16161626. https://doi.org/10.3168/jds.2010-3180.

Rollin, E., K. C. Dhuyvetter, and M. W. Overton. 2015. The cost of clinical mastitis in the first 30 days of lactation: An economic modeling tool. Prev. Vet. Med. 122:257-264. https://doi.org/10.1016/j prevetmed.2015.11.006

Rowbotham, R. F., and P. L. Ruegg. 2016. Associations of selected bedding types with incidence rates of subclinical and clinical mastitis in primiparous Holstein dairy cows. J. Dairy Sci. 99:47074717. https://doi.org/10.3168/jds.2015-10675.

Santman-Berends, I. M. G. A., R. G. M. Olde Riekerink, O. C. Sampimon, G. van Schaik, and T. J. G. M. Lam. 2012. Incidence of subclinical mastitis in Dutch dairy heifers in the first 100 days in lactation and associated risk factors. J. Dairy Sci. 95:2476-2484. https://doi.org/10.3168/jds.2011-4766.

Schukken, Y. H., D. J. Wilson, F. Welcome, L. Garrison-Tikofsky, and R. N. Gonzalez. 2003. Monitoring udder health and milk quality using somatic cell counts. Vet. Res. 34:579-596. https://doi.org/10 .1051 /vetres:2003028.

Sheldrake, R. F., R. Hoare, and G. McGregor. 1983. Lactation stage, parity, and infection affecting somatic cells, electrical conductivity, and serum albumin in milk. J. Dairy Sci. 66:542-547. https://doi .org/10.3168/jds.S0022-0302(83)81823-2.

Supré, K., F. Haesebrouck, R. N. Zadoks, M. Vaneechoutte, S. Piepers, and S. De Vliegher. 2011. Some coagulase-negative Staphylococcus species affect udder health more than others. J. Dairy Sci. 94:2329-2340. https://doi.org/10.3168/jds.2010-3741.

Verbeke, J., S. Piepers, K. Supré, S. De Vliegher, and S. De Vliegher. 2014. Pathogen-specific incidence rate of clinical mastitis in Flemish dairy herds, severity, and association with herd hygiene. J. Dairy Sci. 97:6926-6934. https://doi.org/10.3168/jds.2014-8173.

Wilson, D. J., R. N. Gonzalez, and H. H. Das. 1997. Bovine mastitis pathogens in New York and Pennsylvania: Prevalence and effects on somatic cell count and milk production. J. Dairy Sci. 80:25922598. https://doi.org/10.3168/jds.S0022-0302(97)76215-5.

Yang, F. L., C. Shen, and B. X. He. 2015. The prevalence of heifer mastitis and its associated risk factors in Huanggang, Central China. Trop. Anim. Health Prod. 47:87-92. https://doi.org/10.1007/ s11250-014-0689-z. 